\title{
THE NEW GNOSIS AND THE DENIAL OF ONTOLOGICAL DIFFERENCES
}

LA NUEVA GNOSIS Y LA NEGACIÓN DE LAS DIFERENCIAS ONTOLÓGICAS

\section{Jesús Ballesteros*}

\begin{abstract}
The current transhumanist or posthumanist movements continue the thesis of the old gnosis devaluing the creation like something imperfect. Its novelty is to believe in the possibility of overcoming the creation thanks to technology (biotechnology and bionics). The ideology of gender partly anticipates this way of thinking by devaluing the somatic difference between male and female. This denial of the differences then applies to those existing between the human and the non-human (on one side the primates, and on the other the computer). Posthumanism and transhumanism believe that technology will not only overcome the ontological differences, which form the human, but also the so-called boundary situations, such as illness, suffering and death itself. In this case, by copying the brain information as software to a hard disk. The intellectual myopia of these movements is clear: they reduce the scope of knowledge to mere genetic or electronic information, denying knowledge and, more importantly, wisdom. Their current success is due to their connection with the central thesis of financial capitalism: the need for total manipulation of the real and indefinite growth. Far from advancing the human being, they create malfunctions.
\end{abstract}

Keywords: Boundary-Situations, Creation, Gender Ideology, Indefinitive Growth, Transhumanism

\footnotetext{
* Professor Emeritus of Philosophy of Law and Political Philosophy at University of Valencia (Spain). jesus.ballesteros@uv.es.
} 
Resumen: Los actuales movimientos transhumanistas o posthumanistas continúan la tesis de la vieja gnosis, desvalorizando la creación como algo imperfecto. Su novedad es creer en la posibilidad de superar la creación gracias a la tecnología (biotecnología y biónica). La ideología de género anticipa, en parte, esta forma de pensar, devaluando la diferencia somática entre hombre y mujer. Esta negación de las diferencias se aplica entonces a las que existen entre lo humano y lo no humano (de un lado, los primates, y de otro, el ordenador). El posthumanismo y el transhumanismo creen que la tecnología no solo superará las diferencias ontológicas, que conforman lo humano, sino también las llamadas situaciones extremas, como la enfermedad, el sufrimiento y la misma muerte (en este caso, copiando la información del cerebro como software a un disco duro). La miopía intelectual de estos movimientos es clara: reducen el alcance del conocimiento a mera información genética o electrónica, negando el conocimiento y, lo que es más importante, la sabiduría. Su éxito actual se debe a su conexión con la tesis central del capitalismo financiero: la necesidad de una manipulación total del crecimiento real e indefinido. Lejos de hacer crecer al ser humano, estas corrientes crean disfunciones.

Palabras clave: Situaciones-límite, creación, ideología de género, crecimiento indefinido, transhumanismo

Summary. I. Introduction. II. The New Gnosticism and the Denial of the Ontological Differences. III. Denial of the Inevitable Deficiencies and the Increase of Inequalities, Technolatry and Market Society. IV. Recover Sanity. V. Conclusions. References.

\section{INTRODUCTION ${ }^{1}$}

The essence of the old gnosis was the opposition to the idea of creation, due to the conviction of living in a world created by a perverse demiurge who seeks our perdition ${ }^{2}$. The current gnosis, represented by the poorly titled posthumanism and transhumanism, still stands firm on the rejection of the idea of creation, but at the same time considers that it can be improved and even surpassed due to the technological progress. In his book The New Science of Politics, Eric Voegelin (1987) wrote:

\footnotetext{
${ }^{1}$ English translation by Mari Luz Sáez.

${ }^{2}$ Marcion of Sinope and Valentinus of Alexandria are some of the most important Gnostics, who were criticised by Irenaeus Lyon and Tertullian, among others. There are many books from various authors on this subject, including Hans Jonas, The Gnostic Religion (1963), as well as Pope Benedict XVI, The God of Jesus Christ (1979) and Church Fathers (2008).
} 
«In classic and Christian ethics, the first of the moral virtues is sophia or prudentia, because without adequate understanding of the structure of reality, including the condition humana, moral action with rational co-ordination of means and ends is hardly possible. In the Gnostic dream world, on the other hand, nonrecognition of reality is the first principle» (p. 169).

This gnostic dream characterises all those who currently hope to overcome the human species with the help of the technique, which is known by the pretentious names of transhumanism and posthumanism. These two terms can be considered synonyms, but it is possible to distinguish them depending on what the human being is compared to, i.e., an ape, according to the former, or artificial intelligence, according to the latter. In the first case, genetic engineering is the preferred resource; in the second, the hybridization with artificial intelligence.

\section{THE NEW GNOSTICISM AND THE DENIAL OF THE ONTOLOGICAL DIFFERENCES}

In the XIX century, authors such as Feuerbach, Marx, Comte and Nietzsche show the obviously anti-theistic face of Gnosticism (Voegelin, 1986) ${ }^{3}$. In the XX and XXI centuries, antitheism becomes implicit, because "the death of God" is assumed as fact. The main focus here is the attempt to overcome creation and procreation by producing and reproducing techniques that impose quality control on the laws of human desire (Ballesteros, 2013) .

Transhumanism and/or posthumanism must be placed within the new movement of Gnosticism which professes a blind faith under the power of the technique. It starts from the total homogeneity of reality: everything can be replaced and hybridized. This contrasts with the recognition of plurality of reality, as insisted by classical thinkers from Aristotle to Brentano. The homogeneity of the real has followed a triple process: reduction to mathematics, reduction to computer science and reduction to money.

3 This great insight by Gilbert Keith Chesterton (1950) very much applies to the posthumanist and transhumanist gnosis:

«The madman is not the man who has lost his reason. The madman is the man who has lost everything (especially the contact with reality) except his reason, a reason which serves him only to isolate him in his unreality» (p. 32).

${ }^{4}$ This approach builds upon the Neoclassical school of Economics. 
(i) Regarding the similar effect of the mathematization of reality, Bergson, throughout his work, and Husserl, in his book The Crisis of European Sciences and Transcendental Phenomenology highlighted how the mathematization process of the world, which begins with Descartes ${ }^{5}$, led to the homogeneity and dehumanization of the real.

(ii) The reduction of reality to information in the XX and XXI centuries is what is known by the name of dataism or informational reductionism.

(iii) The reduction of reality to money, i.e., monetization, is the core aspect of the market society, intimately linked to financial capitalism. We will look at this later.

The denial of ontological differences occurs in various fields and the emphasis on each of them gives rise to the various forms of dehumanism. In all cases, the fundamental denial is the denial of consciousness as self and moral consciousness, taking into account that the latter is reduced to the brain.

The transhumanist movement, as a movement denying the difference between what is human and what is not, is preceded and prepared by something apparently and truly less radical - the gender ideology. This denies the somatic difference between male and female, claiming that the only relevant thing is the desire, the impulse. Therefore, people who simply speak out about the differences between a man and a woman are falsely accused of being sexist, instead of the ones who preach male's superiority over females. With the gender ideology, we see an emphasis on rejection of the family structure and the natural procreation, with a goal to replace them with artificial or technological ${ }^{6}$ reproduction. This produces important economic benefits (while simultaneously emulating them: reproducing money with money) and allows for quality control, suppressing the disabled. The gender ideology backs up the thesis of complete manipulability of reality according to desire ${ }^{7}$.

\footnotetext{
${ }^{5}$ Descartes himself seems to have been aware of the risks of his philosophy when, in a letter dated June 28, 1643, with responsible concern, he recommends to Princess Elisabeth of Bohemia that she spends more time strolling and talking with her friends than studying her philosophy.

${ }^{6}$ Donna Haraway insists on this in her Cyborg Manifesto (2003), who admits that cyborgs are illegitimate children of militarism and patriarchal capitalism, but as they are illegitimate, they are unfaithful to their origins: they do not need their father or mother. John Money, the guru of the gender ideology, supports the innocuous character of paedophilia (see Perucchietti \& Marletta, 2015, p. 149).

${ }^{7}$ It is also important to point out that denial of the sexual differences goes together with the emphasis on the differences between races. One of the most meaningful cases is that of the Planned Parenthood movement, founded by Margaret Sanger, which called for the elimination of the black people through abortion, and thus enjoyed the support of the $\mathrm{Ku}$ Klux Klan (Sanger, 1922). The three phases for the elimination of sex as a category are the
} 
A step towards posthumanism, in a less improper sense, consists of denial of the differences between human beings and other species, especially between humans and primates, as proposed by the Great Ape Project. In this case the enemy is humanism, determined to maintain the difference between humans and primates, which happens to be qualified as "speciesism". Here the liberation lies in denying consciousness and unleashing the impulses. This idea was initially supported by utilitarianism, but later also gained ground with sociobiologists ${ }^{8}$, as well as ludic neonietzschians, such as the French poststructuralists (Artaud, Deleuze, Foucault, Donna Haraway and Braidotti) who deny the unity of the individual and propose a body without organs or meaning, one that is completely manipulable at the service of the principle of pleasure. They are zoecentric and followers of dadaism, advocates of the irrational and of the unconscious. They accuse anyone who points out the differences between humans and apes ${ }^{9}$ of being speciesist, since they claim their equivalence, given their genetic proximity. Hybridization with animals is supported as liberation (Braidotti, 2013, p. 66). This type of dehumanism loses, above all, the idea of the unity of the human being, of a human as an in-dividual, which is lost with its fragmentation ${ }^{10}$. Denial of the differences between humans and apes is significantly linked with the denial of unconscious human's right to life, as is the case of Peter Singer ${ }^{11}$.

recognition of "gender identity", the recognition of "self-appointed registered gender" and the elimination of the legal category of "sex". Outstanding examples of this movement are John Money (1996) and Judith Butler (2007), the driving force behind this queer movement. These movements eliminate the reality of women and therefore make it impossible to fight their discrimination. For examples of opinions against the erasure of sex, see Palazzani (2011) and Fernández \& Aparisi (2021).

${ }^{8}$ See Sanmartín (1987).

${ }^{9}$ In 1926 biologist I. I. Ivanov, under Stalin's orders, attempted the hybridization of a man and an ape with the aim of achieving a resilient sub-human without a desire for food and insensitive to pain (for more on this topic, see Faggioni, 2009). The man-animal sexual relationship has been promoted by the Playboy Foundation and Peter Singer as well (for more on this, see Perucchietti \& Marletta, 2015, p. 46). Indeed, the lack of ontological difference between humans and non-humans is a nihilist element, central to capitalism (for more about this, critically Alba Rico (2007), where, together with Gunther Anders defends the need for an "ontological conservatism", as it is indispensable for the critique of today's society. About his, also Bellver (2021, p. 84).

${ }^{10}$ With a premonitory tone Sergio Cotta warned about the need to defend the individual dimension of the human being in order to oppose the contemporary reductionisms. More about this in Ballesteros (2007a).

${ }^{11}$ As Singer (1979) wrote: 
In the case of dataism or informationalism, what is denied is the difference between intelligences (between humans and computers). Dataism has its roots between engineers from different fields of MIT, Boston and information technology companies in Silicon Valley, South San Francisco, such as Google and Facebook (Ballesteros Soriano, 2020). Since the invention of cybernetics in the late 1940's, the complex of inferiority of the human being before the machine, which initiated with futurism, is now expressed as a complex of inferiority to information. It begins with feeling envious of computers, because they are faster and more precise when processing information. It asserts that nature is today's database ${ }^{12}$ and humanity ends up reduced to simple genetic or electronic information, in such a way that every human "thing" becomes subject to manipulation and intended improvement via Emerging GNR Technologies: genetics, nanotechnology and robotics (Ballesteros, 2007b, p. 22). Everything can be replaced. It is the primacy of the substitute. This type of dataism ignores the essential distinction between the different levels of understanding reality, which go from wisdom to information, through knowledge. Neglect of this distinction was first described in 1934 by the great Anglo-American poet Thomas Stearns Eliot (1958), in his poem Choruses from the Rock:

«Where is the wisdom we have lost in knowledge?

Where is the knowledge we have lost in information?» (p. 96). ${ }^{13}$

Indeed, it is unknown that "an animal is superior to a computer because it recognizes and accesses the field of semantics, even though it does not know and does not reflect, while the computer does not go beyond the syntactic level" (Llano, 1999, p. 180). Human wisdom is more than knowledge because it brings meaning. Human intelligence is emotional and sentient (Zubiri, 1999).

Dataism equally ignores the human totality and its condition of being unique, pretending to add something to the human being. It is the passion for hybridization. It actually disdains the biological body, considering it

«Human babies are not born self-aware, or capable of grasping that they exist over time. They are not persons [therefore] the life of a newborn is of less value than the life of a pig, a dog, or a chimpanzee» (p. 122).

12 See Lyotard (1984). In this respect Lyotard is clearly transhumanist, rather than posthumanist. Heidegger (1966) had already warned in his interview Nur noch ein Gott kann uns rette that "cybernetics is the science that seeks to replace philosophy today".

${ }^{13}$ An anticipated critic of dataism is found in the short story of Jorge Luis Borges (1944), Funes the Memorious, in which he tells how the main character ends up immobilized because he lacks judgement towards the accumulation of data that he possesses in his memory. 
obsolete, due to its fragility and susceptibility to pain and suffering and it wants to replace it with a silicone body. However, far from achieving immortality, these techniques produce malfunctions. It is no coincidence that its supporters are often called Extropians.

A society which believes in hegemony of information is also one which places money at the forefront and does not accept limit and deficiency as reality, thus considering that everything is venal, replaceable and easily manipulated ad libitum. The gender ideology is, thus, indebted to the Neoclassical school of economics in two senses: firstly, by the exaltation of desire over work: "Work has only arms; desire has wings" (Ballesteros, 2021) and secondly, due to the consideration that all reality (human beings and nature, or "human capital" and "natural capital", to use the Neoclassical terminology) can be replaced by capital. This causes the financialization of every field: economics, politics and culture ${ }^{14}$.

In accordance with this movement, which has been responsible for the global economy since 1971 and is gradually accentuated, everything becomes an object of trading. A price is put on everything and what cannot produce an immediate profit is rejected, which is what Pope Francisco has described as culture of discard, or Bauman (2015) - culture of waste. Financialization is linked to technolatry, the devotion to the technique, the consideration that the technique, created by man is superior to the man himself and to nature. There is, therefore, the need to deny all order in nature, including human life, and replace everything with machines, especially with robots and cyborgs. Financialization and technolatry go together with what is known as dataism.

\section{DENIAL OF THE INEVITABLE DEFICIENCIES AND THE INCREASE OF INEQUALITIES, TECHNOLATRY AND MARKET SOCIETY}

Denial of the aspects discussed above, of the natural and the created is, therefore, a desire to build a perfect entity with no limits or vulnerabilities. To do so we must deny the ontological, and the distinction between what is avoidable and what is not. This occurs in, both, the struggle against differences and in the struggle against vulnerabilities.

\footnotetext{
${ }^{14}$ The fact that today the new Left joins the ideology of the genre evidence what Marx had highlighted in the first part of The Communist Manifesto, about the need of continuing the well-of mentality with respect to religion, marriage, family, faithfulness, tradition, and authority.
} 
Transhumanism believes in the possibility of overcoming death physically, or, more precisely, electronically. One of the most noteworthy individuals who believe this idea is the leader of transhumanists and professor at the University of Oxford, Nick Bostrom, who has complete faith that new technology, and especially the Internet, will help overcome biological limitations, including death, by means of post-biological existence (Bostrom \& Savulescu, 2009). Bostrom writes (2001):

«The source of advances that lead us to paradise on Earth is information. More and more people are gaining access to the Internet. Programmers, software designers, IT consultants and others are involved in projects that are constantly increasing the quality and quantity of advantages of being connected. [...] Likewise, superintelligence, based on the ability of self-learning systems, is any intellect that vastly outperforms the best human brains in practically every field, including scientific creativity, general wisdom, and social skills. Several scientists have argued that both the hardware and the software required for superintelligence might be developed within a few decades» (p. 128).

He ends his thesis with this paragraph:

"If we could scan the synaptic matrix of a human brain and simulate it on a computer then it will be possible to migrate from our biological embodiments to a purely digital substrate. By making sure that we always had back-up copies, we might then enjoy effectively unlimited life-spans» (p. 132). ${ }^{15}$

This operation would require a computer capable of re-creating the 100 trillion connections that the human brain has ${ }^{16}$.

Transhumanist's interests coincide with those of the large communications companies, which have their headquarters in Silicon Valley, South San Francisco. The best spokesperson for this technocratic transhumanism is the engineer and financier Ray Kurzweil (1948). His pretence is to get a "version 2.0" of the human body through three phases. The first still remains in the realm of common sense: healthy life through food and physical exercise. The second phase is already risky and involves the use of genetic engineering and biotechnology to combat cellular aging. And the third phase, the truly transhumanist one, is aberrant and would be

\footnotetext{
${ }^{15}$ An excellent criticism of Nick Bostrom is included in Postigo (2009).

${ }^{16}$ Hannah Chritchow, neuroscientist of the University of Cambridge is working on this. The Human Brain Backup Group, made up of researchers from six different countries, claims that in two years they will have carried out the first complete copy of all connections of a human brain and will be able to store it on an electromagnetic medium, in this case, highcapacity hard disks.
} 
based on the development of nanotechnology and artificial intelligence in order to reconstruct the entire body and brain on a molecular level ${ }^{17}$.

The key name for this is Singularity, introduced by the science fiction author Vernor Vinge ${ }^{18}$. Progress here would be entrusted onto hardware, according to Gordon Moore's law, whereby the number of transistors on a chip doubles every two years (as opposed to human evolution). "Since electrons have a shorter distance to travel, the circuits are faster" (Kurzweil, 2008) ${ }^{19}$. But Kurzweil's entire construct is based on a fundamental contradiction, since his conviction of the artificial brain's superiority over the human one, due to its greater speed, contrasts with his lucid affirmation of the irreducibility of knowledge over information, as he (2008) writes: "intelligence selectively destroys information to create knowledge" (p. 370); this selective destruction of information takes time and is totally opposed to speed $^{20}$. Perhaps, what mostly concerns Kurzweil (2008), beyond these contradictions, is "singularity as an economic imperative" (p. 88). Singularity for him expresses the inevitability of exponential growth. Manifestation of this belief is his work for Google and the creation, under his patronage, of the University of Singularity of Silicon Valley, where he was the first Rector. His utilitarianism is, therefore, not only theoretical, but makes business by selling its products to achieve permanent youth ${ }^{21}$.

The reduction of knowledge to simple information and its technological enthusiasm is what, in turn, prevents posthumanism from

${ }^{17}$ See Kurzweil \& Grossman (2004, pp. 4-5). As Barry Commoner (1971) states: "Intending to control evolution is extremely serious since nature knows best. It seems dangerous trying to improve instantaneously what nature has taken half a million years to form".

${ }^{18}$ In his 1993 article Technological singularity, for NASA's Whole Earth Review, the author states that "the Singularity, that its coming is an inevitable consequence of human's natural competitiveness and the possibilities inherent in technology".

${ }^{19}$ For more about singularity, watch the film Transcendence (Pfister, 2014) in which it is said that "Transcendence, as a copy of the human brain as computer software, is the real name for singularity" as well as the documentary Transcendent Man (Ptolemy, 2009), dedicated to Kurzweil, although some slight criticisms are present.

${ }^{20}$ Criticism of speed as the basis of dehumanization is one of the key points in Paul Virilio's work (1999).

${ }^{21}$ In his work, Transcend: Nine Steps to Living Well for Ever (2009), Kurzweil predicts an future identifiable with virtual eternity. Similarly, in his technocratic ingenuity, Hans Moravec (1988) believes that the greater speed of robotics will suppose the superiority of the artificial brain over the human one. Furthermore, Yuval Noah Harari who in his pretentious and fallacious book Homo deus (2015) in which he considers that the stage of homo sapiens as well as his concerns for the fight against hunger, plague and war have been overcome. Harari is a perfect example of the typical author phenomenon undeservedly elevated by social networks, and specifically by the CEO of Facebook, Mark Zuckerberg. An excellent critique of Harari can be found in Llano Alonso (2018). 
establishing the decisive distinction between the avoidable and the unavoidable in the realities of illness, suffering and death. No wonder the American thinker Reinhold Niebuhr put the key to wisdom in his famous serenity prayer of 1937: "God, grant me the serenity to accept the things I cannot change, the courage to change the things I can, and the wisdom to know the difference".

It is true that the Stoics, in particular Epictetus (1983), had already emphasized the importance of the distinction between what does, and does not depend on us, but they failed to establish it, by relating it to the impossibility of human self-sufficiency ${ }^{22}$. It is, therefore, necessary to distinguish between the unavoidable and the avoidable, but without losing sight of the essential human vulnerability and its "creature" status.

There are avoidable deaths, millions of avoidable deaths annually. According to reports of the United Nations Commission on Human Development, less than a million people die each year from violent acts, and around 15 million, including 10 million children, from preventable diseases such as malaria, measles and diarrhoea, caused by perfectly modifiable empirical conditions, such as insalubrity, lack of drinking water, lack of food and medicine. For a major part of contemporary society, the eradication of such avoidable deaths (Ballesteros, 2009) ${ }^{23}$ constitutes the core of human rights and global justice.

There are avoidable deaths, but death, suffering and disease, as such, are unavoidable, as they are linked to the ontological reality of the human being, as a contingent and finite being, derived from its "creature status" 24 .

\section{RECOVER SANITY}

Neither Benedict XVI nor Francis have mentioned the terms transhumanism or posthumanism, but from their teachings, a perfect understanding of the phenomenon and its criticism can be deduced.

For Benedict XVI (2005) the main danger of the present is the Gnostic contempt for creation and its mission to develop a new one, in which the man-made replaces the natural, and everything can be subjected to quality control according to the criteria of calculation and efficiency (p. 51).

\footnotetext{
${ }^{22}$ Hence the Stoic influence had negative consequences on modern thought (Taylor, 1989). See also Ballesteros (1998).

${ }^{23}$ On the contrary in the transhumanism, one breathes the indifference of Friedrich Nietzsche (1989), "But what doth human distress matter to me!" (4 ${ }^{\text {th }}$ Part).

${ }^{24}$ Transhumanism denies the Grenzsituationen (Boundary-Situations) of Karl Jaspers. On this topic there is an excellent essay by Lafontaine (2008).
} 
Pope Francis has almost constantly referred to the fact that the radical evil, which, on November $5^{\text {th }}$ of 2016, he called "basic terrorism", consists of having displaced the man and woman from the centre, and put the "money god" in their place ${ }^{25}$. In turn, the Encyclical Laudato si can be interpreted in an antignostic key, wherein establishing that what has been created by God must be considered superior: human beings and nature with respect to what has been created by man: technology and money.

Both Popes are right to not use the terms transhumanism and posthumanism since, as we have seen, there is no transcending human nature within these movements, there is only its destruction. I think the most appropriate name is dehumanism, which denotes the ideas of reductionism and loss (Ballesteros, 2021, pp. 154-170).

This pontifical criticism of dehumanism can be perfectly related to the thoughts of the great Christian authors of the $20^{\text {th }}$ century, among which Gabriel Marcel $^{26}$ is one of the most noteworthy.

In the face of post-humanist ruins, it is necessary to return to normal with the doctor and great German philosopher of existentialism Karl Jaspers (1932), who spoke about Grenzsituationen (Boundary-Situations) as "situations characterized by their inevitability, which we cannot avoid and that we cannot alter" like illness, suffering and death. It is in such situations that the sense of transcendence surfaces and humans may manage to recover and overcome themselves, as well as all wisdom and all true knowledge.

Following Karl Jaspers, Viktor Frankl (1977) highlights how the key to human greatness responds to their ability to respond meaningfully to suffering:

«The values of attitude when faced with extreme situations are more excellent than the creative values of homo faber, and the experiential ones of homo amans, in that the sense of suffering is higher than the sense of work and the sense of love» (p. 117).

Their categories are not success or failure but fulfilment or despair. In this lies the superiority of the homo patiens over the homo faber: his goal, the fulfilment of despair, can occur under any circumstance, whereas the goal of homo faber demands success: "Homo patiens can feel fulfilled even in the most blatant failure" (Frankl, 1977, p. 95).

This vision of the meaning of suffering and of life as fulfilment, and not as success, implies the recognition of the spiritual dimension as key to

\footnotetext{
${ }^{25}$ In-flight press conference of His Holiness Pope Francis from Poland to Rome, 2016.

${ }^{26}$ In his books, Les hommes contre l'humain (1951), Le declin de la sagesse (1954), and L’homme problematique (1955). About this, see Fernández (2007).
} 
the human being (Frankl, 1975). To suffer means to grow and mature. It also favours the understanding of one another. As Aeschylus said: "He who has suffered has the joy of understanding another". That is why Frankl in the opinion discussed by Scheler and Rilke, defends the right to live the boundary situation of suffering. On this, Ivan Illich (1976) defends ascesis, which assumes that the most difficult effort is to be able to fight against the homogeneity and neutralization of technology.

\section{Conclusions}

1. The ancient gnosis despised matter and the human body as forms of evil. Contemporary gnosis not only despises creation but also believes that it is possible to overcome it, and in turn, overcome the homo sapiens species with technology.

2. The starting point of contemporary gnosis is the total homogeneity of the real; as opposed to plurality, in which the classical and Christian school of thought is based, the new gnosis believes that everything can be substituted and/or hybridized and thus the human/non-human distinction can be eliminated. This homogeneity of the real seeks to end ontological differences at all levels, giving rise to gender identity and the erasure of sex, zoe-centric posthumanism, dataist transhumanism and the monetization of nature and work.

3. Gender identity tries to erase the sexual differences between women and men, since everything depends on the instant desire of the subject. This alleged elimination of sexual differences, on which the queer doctrine especially insists, is the greatest danger to the fight against discrimination against women, since they cease to exist as such, as "being female" becomes just a temporary option.

4. Zoecentric posthumanism tries to end the distinction between human and animal through their hybridization, producing a body without organs, without meaning, based solely on the pleasure principle. This continues the poststructuralist line of writers such as Artaud, Deleuze, Foucault, Haraway or Braidotti.

5. Dataist transhumanism relies on GNR (genetics, nanotechnology and robotics) technologies to achieve that the so-called A.I. (Artificial Intelligence) surpasses human intelligence before the year 2030, due to its ability to reach much greater computing speeds; something they call the "technological singularity". From this idolatry of technology, it is believed that physical death is avoidable with the simple scanning of brain information. At the same time, millions of avoidable deaths are ignored, 
from causes such as hunger, pandemics or war, and they are already considered overcome in the new era.

6. Economism, the ally of technocracy, reduces the elements of production - such as nature (improperly designated as natural capital) and human labor (improperly designated as human capital) - to simple capital, which, in turn, causes the monetization of the real.

7. Firstly, in order to restore sanity, it is essential to recover the distinction between Creator and creature and to show gratitude for what is given, as something ontological superior to something man-made. Secondly, it is important to recognize the dignity of every human being (irreducible to animal or cyborg), especially of those who are in boundary situations (illness, suffering or death). These form the perfect opportunity for transcendence and realization of the meaning of life. 


\section{REFERENCES}

Alba Rico, S. (2007). Capitalismo y nihilismo. Dialéctica del hambre y de la mirada. Akal.

Ballesteros, J. (1998). La constitución de la imagen actual del hombre. Tópicos: Revista de Filosofía, 15 (2), 9-29.

Ballesteros, J. (2007a). Sergio Cotta y los retos del siglo XXI. Persona y Derecho, 57, 7180 .

Ballesteros, J. (2007b). Biotecnología, biopolítica y posthumanismo. In Ballesteros, J. \& Fernández, E. (eds.), Biotecnología y posthumanismo, 21-46. Thompson.

Ballesteros, J. (2009). Seguridad humana, derechos y políticas públicas. In Mediterranean Meeting of Young Jurists (Fórum Jávea de Vecindad), Retos de la Justicia Global, 53-59.

Ballesteros, J. (2015). FIVET y medicina del deseo. Medicina y Ética: Revista Internacional de Bioética, Deontología y Ética Médica, 25 (4), 509-516.

Ballesteros, J. (2021). Domeñar las finanzas, cuidar la naturaleza. Tirant lo Blanch.

Ballesteros Soriano, A. (2020). Digitocracy. Ruling and Being Rules. Philosophies, 5 (2), 1-13. DOI: 10.3390/philosophies5020009

Bellver, V. (2021). Transhumanismo, discurso transgénero y digitalismo: ¿exigencias de justicia o efectos del espíritu de abstracción? Persona y Derecho, 84, (On Press).

Benedicto XVI (2005). Creación y pecado. Eunsa.

Borges, J. L. (1944). Funes el memorioso. In Ficciones. Editorial Sur.

Bostrom, N. (2001). Transhumanism: An Idea Whose Time has Come. In Tandy, C. (ed.), Doctor Tandy's First Guide to Life Extension and Transhumanity, 127-140. Ria University Press.

Bostrom, N. \& Savulescu, J. (2009). Human Enhancement Ethics: The State of the Debate. In Savulescu, J. \& Bostrom, N. (eds.), Human Enhancement, 1-24. Oxford University Press.

Braidotti, R. (2013). The Posthuman. Polity.

Butler, J. (2007). Gender Trouble: Feminism and the Subversion of Identity. Routledge.

Chesterton G. K. (1950). Ortodoxia. In Obras (I). Aguilar.

Commoner, B. (1971). The Closing Circle: Nature, Man, and Technology. Knopf.

Eliot, T. S. (1958). The Complete Poems and Plays. Harcourt, Brace \& World, Inc.

Epicteto (1983). The Handbook (The Encheiridion). Hackett.

Faggioni, M. (2009). La natura fluida: le sfide dell'ibridazione, della transgenesi, del transumanesimo. Studia Moralia, 47 (2), 387-436. 
Fernández, E. (2007). Crítica filosófica del posthumanismo. In Ballesteros, J. \& Fernández, E. (eds.), Biotecnología y posthumanismo, 81-108. Thompson.

Fernández, E. \& Aparisi, A. (2021). Hacia un modelo de sexo-género de igualdad en la diferencia. Tirant lo Blanch.

Frankl, V. (1975). Der leidende Mensch. Anthropologische Grundlagen der Psychotherapie. Huber, Bern.

Frankl, V. (1977). Man's Search for Meaning. An Introduction to Logotherapy. Beacon Press.

Harari, Y. N. (2016). Homo Deus. A Brief History of Tomorrow. Harper Collins.

Haraway, D. (2003). Cyborg, Coyotes, and Dogs: A Kinship of Feminist Figurations and There are Always More Things Going on Than You Thought! Methodologies as Thinking Technologies. Routledge.

Heidegger, M. (23-IX-1966). Interview of 23, IX, 1966, "Nur noch ein Gott kann uns rette". Der Spiegel.

Illich, I. (1975). Némesis médica. La expropiación de la salud. Seix Barral.

Jaspers, K. (1959). Filosofía (II). Universidad de Puerto Rico.

Jonas, H. (1963). The Gnostic Religion. Beacon Paperback.

Kurzweil, R. (2008). La singolarità e vicina. Feltrinelli.

Kurzweil, R. (2009). Transcend. Nine Steps to Living Well for Ever. Rodale Inc.

Kurzweil, R. \& Grossmann, V. (2004). Fantastic Voyage. Live Long Enough to Live Forever. Rodale Books.

Lafontaine, C. (2008). La Société postmortelle. La mort, l'individu et le lien social à l'ère des technosciences. Seuil.

Llano, A. (1999). Humanismo cívico. Ariel.

Llano Alonso, F. (2018). Homo excelsior. Los límites ético-jurídicos del transhumanismo. Tirant lo Blanch.

Lyotard, F. (1984). The Postmodern Condition. University of Minnesota Press.

Money, J. (1996). Man and Woman, Boy \& Girl: Gender Identity from Conception to Maturity. Jason Aronson.

Moravec, H. (1988). Mind Children. The Future of Robot and Human Intelligence. Harvard University Press.

Nietzsche, F. (1989). Also sprach Zarathustra. In Werke. Walter de Gruyter.

Palazzani, L. (2008). Identità di genere? Dalla differenza alla in-differenzan sessuales nel diritto. Cinisello Balsamo.

Palazzani, L. (2011). Sex/gender. Gliequivoci dell'uguglianza. Giappichelli.

Perucchieti, E. \& Marletta, G. (2015). Unisex. Cancellare l'identità sessuale, la nuova arma della manipolazione globale. Arianna.

Pfister, W. (2014). Transcendence [film]. Warner Bros. 
Postigo, E. (2009). Transumanesimo e postumano: principi teorici e implicazioni bioteche. Medicina e Morale, 2, 267-282.

Ptolemy, R. B. (2009). Transcendent Man [film]. Ptolemaic Productions, Therapy Content.

Sanger, M. (1922). Woman, Morality and Birth Control. New York Publishing Company.

Sanmartín, J. (1987). Los nuevos redentores. Reflexiones sobre la ingeniería genética, la sociobiología y el mundo feliz que nos prometen. Anthropos.

Taylor, C. (1989). Sources of the Self. The Making of the Modern Identity. Harvard University Press.

Vinge, V. (1993). Technological Singularity, Whole Earth Review. Winter.

Virilio, P. (1999). Politics of the Very Worst. Semiotext(e).

Voegelin, E. (1986). The Political Religions. E. Mellen Press.

Voegelin, E. (1987). The New Science of Politics: An Introduction. University of Chicago Press.

Zubiri, X. (1990). Inteligencia sentiente. Alianza. 